\title{
IMPLEMENTASI KESELAMATAN DAN KEAMANAN KAPAL- KAPAL YANG BERLABUH (DROP ANCHOR) DI WILAYAH PERAIRAN BATAM
}

\author{
Awang Sasongko* \\ PT. Tosan Aji Mumpuni, Batam - Indonesia
}

\begin{abstract}
The main purpose of this research is to understand the role of Syahbandar in the execution of shipping activities in sea freight in territorial waters according to "Act Number 17 of 2008" about shipping in Indonesia. The formulation of the problem consists of: (1) What is the minimum operating standard that must be owned by a ship that is anchored ? ; (2) Who has the highest authority in maintaining the safety and security of anchored ship ? ; (3) Has "Act Number 17 of 2008" been implemented correctly? The method used in the research is juridical-sociological approach in the form of field survey and direct interviews with Stakeholder. The type of data used in the research is descriptive analysis method to solve the problem at hand.
\end{abstract}

Keywords: Syahbandar, Shipping, Law number 17 of 2008

\begin{abstract}
Abstrak
Tujuan utama dari penelitian ini yaitu guna mengetahui dengan pasti peran Syahbandar dalam pelaksanaan aktifitas pelayaran di dalam angkutan laut di wilayah perairan berdasarkan aturan perundang undangan "Nomor 17 Tahun 2008" tentang pelayaran di Indonesia. Adapun rumusan masalah penelitian meliputi: (1) Bagaimana standard operasi minimum yang harus dimiliki kapal yang sedang berlabuh? ; (2) Siapakah kewenangan tertinggi dalam menjaga keselamatan dan keamanan kapal-kapal yang berlabuh? ; (3) Apakah "Undangundang Nomor 17 Tahun 2008" sudah diimplementasikan dengan benar ? Metode penelitian yang digunakan dalam penelitian ini ialah metode pendekatan secara yuridis sosiologis yang berupa survei di lapangan dan wawancara langsung dengan Stakeholder. Jenis data yang digunakan dalam penelitian ini adalah metode deskriptif analis dipergunakan untuk memecahkan permasalahan. Kata kunci: Syahbandar, Pelayaran, Undang - Undang no 17 tahun 2008
\end{abstract}

* Alamat Korespondensi : awang_sasongko@pancautama.com 


\section{A. Latar Belakang Masalah}

Siapa yang tidak kenal Indonesia yakni sebuah negara dengan banyak pulau, Indonesia merupakan negara kepulauan terbesar secara geografis dan dapat dilihat melalui peta bumi bahwa Indonesia mempunyai letak strategis yang diapit oleh dua benua besar dan ditengahtengah dua samudera luas yang membentang, apalagi ditinjau dari segi perekonomian lalu lintas perdagangan dunia maka Indonesia memiliki posisi sangat menguntungkan khususnya perdagangan dari dalam dan keluar karena sebagian besar melalui wilayah perairan Indonesia. Dimana alat angkutan sebagai transportasi perdagangan yang ekonomis adalah dengan menggunakan kapal laut.

Batam $^{1}$ merupakan satu pulau diantara 326 pulau yang masih dalam gugusan wilayah Kepulauan Riau terletak antara Selat Malaka dan salah satu ngara adidaya yaitu Singapura. Pada awalnya, Batam adalah merupakan pulau yang kosong dan masih semacam hutan yang rimbun sehingga nyaris tanpa kehidupan, walaupun ada beberapa penduduk asli yang terlebih dulu bertempat tinggal di pulau ini dengan mempunyai penghasilan sebagai nelayan dan petani tradisional, namun sedikit yang terlibat dalam mengubah secara fisik bentuk pulau Batam. FTZ ${ }^{2}$ selama beberapa Tahun sejak Batam berkembang mulai diterapkan luas hingga Bintan dan pulau Karimun sehingga mengacu pada UU No. 46 Tahun 2007 tentang sebuah kawasan yang memiliki perdagangan bebas dan pelabuhan bebas Batam untuk kemajuan yang telah dicapai, seperti ketersediaannya sumber mata pencaharian usaha yang dapat mampu menampung lapangan pekerjaan. Sebagai daerah yang memiliki potensi luar biasa dan berkembang pesat, Batam juga mempunyai banyak masalah untuk itu diperlukan penyempurnaan serta pengembangan agar dapat melengkapi kekurangan-kekurangan yang ada seperti perlu ditingkatkan pada sektor industri, alih kapal, perdagangan dan pariwisata. Pulau Batam terletak pada jalur pelayaran internasional yang mana merupakan sebuah pulau yang terletak di wilayah strategis, karena langsung berbatasan dengan negara tetangga seperti negara Singapura dan negara tetangga lainnya yakni Malaysia.

Dengan posisi geografis dan kondisi yang semakin berkembang, Batam akan semakin banyak disinggahi oleh kapal-kapal, baik dari dalam negeri maupun asing, untuk keperluan bongkar muat, arus pelayaran ataupun yang berlabuh (Drop Anchor) di sekitar perairan untuk tujuan perbaikan ataupun menunggu penyewa. Banyaknya kapal-kapal yang berlabuh di sekitar perairan Batam, membutuhkan sistem pengamanan

1 Muchid Albitani, Berburu Rente di Pulau Batam, (Yogyakarta: Deepublish, 2016), hlm 37.

2 Indonesia, Peraturan Pemerintah Republik Indonesia tentang Kawasan Perdagangan Bebas dan Pelabuhan Bebas Batam, PP No. 46 Tahun 2007, pasal 1 butir 2. 
yang lebih baik untuk meningkatkan kepercayaan dari pihak pemilik kapal, terutama pemilik kapal asing.

Pelabuhan merupakan infrastruktur penting dalam melakukan peranan sebagai transportasi laut ${ }^{3}$. Untuk itu pemerintah tengah mempersiapkan dan melakukan penyediaan infrastruktur yang tidak kalah penting peranannya dalam membangun kawasan terpadu ini, pembangunan mulai dari kantor pelayanan terpadu satu atap (one stop service $)^{4}$, penggunaan akses jalan, penyediaan listrik, pembangunan penerangan, sarana air bersih, pemanfaatan kepelabuhanan disamping laut dan pelabuhan udara, jaringan komunikasi dan telekomunikasi seperti media cetak, elektronik, telepon dan internet juga sedang digalakkan, disamping itu jaminan keamanan bagi para investor penting peranannya untuk tepatnya pembangunan pemetaan tata ruang wilayah.

Perkembangan pertama dalam bidang keamanan ditandai dengan disepakatinya sebuah konvensi internasional yaitu "1974 United Nations Convention on Safety of Life at Sea"5. SOLAS adalah perjanjian internasional pertama yang mengatur mengenai keselamatan kapal dan menetapkan standar minimal dalam pembangunan, peralatan, serta pengoperasian bagi sebuah kapal.

Undang-undang No. 17 Tahun 2008 menyebutkan bahwa pasal 80 tentang fungsi keselamatan dan keamanan pelayaran dilaksanakan oleh Syahbandar. Secara eksplisit dalam melakukan penyelenggaraan terwujudnya keselamatan dan terciptanya keamanan di laut, Syahbandar berkoordinasi dengan Badan Kesatuan Penjagaan Laut dan Pantai atau Indonesia Sea and Coasguards.

\section{B. Rumusan Masalah}

1. Bagaimana standart operasi prosedur minimum yang harus dimiliki kapal-kapal yang sedang berlabuh di sebuah perairan sesuai dengan IMO regulation ${ }^{6}$ dan ISPS code untuk menjaga keselamatan dan menjamin keamanannya ?

2. Siapakah kewenangan tertinggi dalam menjaga keamanan dan keselamatan pada kapal-kapal yang berlabuh di perairan sekitar Batam sesuai dengan Undang-undang No.17 tahun 2008 ?

3. Apakah Undang-undang No.17 tahun 2008 sudah di implementasikan dengan benar khususnya pada sektor keamanan kapal-kapal yang berlabuh di perairan sekitar Batam ?

3 Husseyn Umar, Hukum Maritim dan Masalah-masalah Pelayaran di Indonesia, (Jakarta: Pustaka Sinar Harapan, 2001), hlm 235 .

4 Olga Soejono, "Penerapan Peraturan Perundang-undangan di Bidang Pelabuhan dalam Kaitannya dengan Organisasi dan Tata Kerja Administrator Pelabuhan," dalam Peningkatan Peranan Hukum dan Perlindungan Hukum dalam Kegiatan Perhubungan Laut (Jakarta: IND.HILL-CO, 1987), hlm 20.

5 SOLAS. International Convention for The Safety of Life at Sea: Lloyd's Register Rule Finder 2005-Version 9.4

6 Anna Natova, International Maritime Organization (IMO), Implication of The United Nations Convention On the Law of the Sea for The International Maritime Organization (Maritime Administration, 2005) 


\section{C.Metode Penelitian}

Peneliti menggunakan jenis penelitian pendekatan secara yuridis sosiologis dimana akan dilakukan survei di lapangan dan juga wawancara langsung dengan Stakeholder. Metode deskriptif analisis akan dipergunakan untuk memecahkan permasalahan-permasalahan dalam penelitian ini sesuai dengan fakta-fakta ataupun data-data yang terkumpul saat dilakukannya kegiatan penelitian.

Objek penelitian yang akan dilakukan oleh peneliti yakni di wilayah kepelabuhan dan perairan di sekitar Pulau Batam terutama pada kapalkapal yang tengah berlabuh sehingga didapatkan sebuah hasil kajian dari survey yang mana tercatat sejak tahun 2018 di pelabuhan Batam menurut hasilnya bahwa kapal berlabuh di perairan Batu Ampar 1.935 Kapal; sedangkan Perairan Kabil: 212 Kapal; dan tercatat di Perairan Tanjung Uncang/Sekupang: 1.246 Kapal. Dengan data yang tercatat tersebut maka dipastikan pertumbuhan dan perkembangan investasi di perairan Batam menguat setiap tahunnya.

Peneliti melakukan kegiatan wawancara terhadap pemilik kapal DJN Ship dan MERATUS Ship, kemudian dari Instansi pemerintah yaitu Syahbandar, pejabat Pangkalan Angkatan Laut serta Bakamla. Antusias dari kegiatan wawancara dengan metode questionnaire dapat terlihat dengan terlaksananya kegiatan survey dan pengumpulan data.

Dalam teknik pengumpulan data, peneliti membaginya menjadi 3 bagian, yakni:

1. Primer: Langsung kontak melalui wawancara dengan Ship Owner, Penyewa Kapal, Bakamla, TNI Angkatan Laut, Lemhamnas dan Syahbandar (administrator pelabuhan laut) di Batam.

2. Sekunder: Data dari Kakanpel, Undang-Undang, Literatur, JurnalJurnal dan pendapat para ahli.

3. Tersier: Kamus, Ensiklopedia.

Peneliti melengkapi kegiatan pengumpulan data dengan melakukan kegiatan survey di tempat lokasi sehingga didapatkan data-data yang baik untuk dapat memberikan kajian data yang nanti dipergunakan untuk penelitian selanjutnya.

Peneliti melengkapi data-data dengan kegiatan survey langsung di lokasi kegiatan berlabuhnya kapal-kapal di pelabuhan Batam sehingga didapatkan suatu hasil pengumpulan data yang baik, meliputi:

1. Observasi.

2. Wawancara/ Interview.

3. Focus Group Discussion (FGD).

Jenis metode dalam menganilisa data yang akan dipergunakan dalam penelitian hukum ini adalah yuridis kualittif dimana penyusunannya dibentuk dalam bentuk uraian kalimat. 


\section{Hasil Penelitian Dan Pembahasan}

1. Standart Operasi Prosedur (SOP) wajib dimiliki kapal-kapal yang sedang berlabuh di perairan sesuai dengan IMO regulation dan ISPS code untuk menjaga keselamatan dan menjamin keamanannya.

Undang-undang Nomor 17 Tahun 2008 tentang Pelayaran menyebutkan mengenai daerah lingkungan kerja pelabuhan beserta tugas dan wewenangnya oleh pihak yang melaksanakan. Berdasarkan peraturan perundang undangan tersebut didalam huruf c, disebutkan: "Tata cara pengaturan dalam bidang terciptanya keselamatan dan mewujudkan keamanan pelayaran pada konvensi internasional memuat ketentuan aturan mengenai terselenggaranya perwujudan teknologi dengan mengacu pada penggunaan peralatan mutahir untuk menumbuh kembangkan perwujudan sarana dan prasarana keselamatan di dalam arus pelayaran, disamping mengakomodasi ketentuan mengenai sistem keamanan pelayaran yang termuat dalam ISPS Code".

Adapun tujuan dari pelaksanaan ditetapkannya International Ships and Port Facility Security Code:

1. Menetapkan kerangka kerja sama international.

2. Menetapkan pejabat yang bertanggung jawab dan setiap anggota tidak terkecuali badan-badan pemerintah ikut berperan serta dibidang industri pelayaran serta kepelabuhanan.

3. Memastikan terkumpulnya maupun saling bertukar informasi sefektif terkait dengan keamanan dan keselamatan di laut.

4. Menyediakan kerangka metodologi penilaian keamanan.

5. Memberikan kejelasan dan pengertian bahwa segala tindak keamanan di bidang maritim telah cukup secara proporsional.

Sesuai SOP (Standard Operational Procedure) yang ada, setiap kapal yang akan berlabuh wajib memenuhi persyaratan dan regulasi yang telah ditetapkan di pelabuhan tersebut. Seperti IMO Regulation, ISPS CODES tentang Facility Port Service, SOLAS tentang Safety, dan memiliki seluruh dokumen lengkap (CSR, SSAS, dll). Seluruh regulasi tersebut harus wajib dimiliki oleh setiap pemilik kapal, dikarenakan sebagai landasan hukum ketika terciptanya kondisi pembajakan atas kapal atau situasi emergency. 


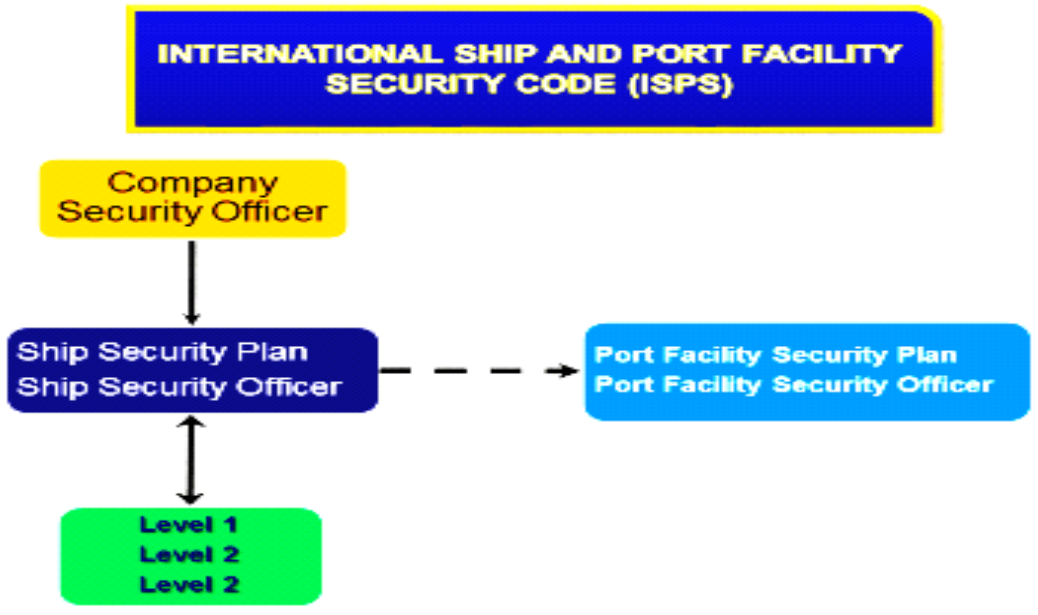

Tabel 1

Langkah Keamanan ISPS Code

Jikalau terjadi pembajakan kapal atau situasi emergency, Ship Security Officer (SSO) harus segera melaporkan kepada PFSO (Port Facility Safety Officer) dan CSO (Company Security Officer) yang dimiliki kewenangannya oleh Syahbandar. Kemudian Syahbandar akan segera mengirim personilnya, dan berkordinasi dengan TNI AL dan POLAIR. Bahkan jika ada tindak kriminal PPNS (Penyidik Pegawai Negeri Sipil) ${ }^{7}$ yang ditugaskan oleh Syahbandar akan menindak lanjuti kasus tersebut.

Dalam ISPS Code ada perbedaan tingkatan level keamanan ${ }^{8}$, antara lain:

Level pengamanan 1: menandakan penunjukkan keamanan yang masih bersifat normal, di tingkat ini dimana kapal maupun fasilitas pelabuhan beroperasi dalam standar minimum.

Level pengamanan 2: menandakan penunjukkan keamanan yang meningkat dari penunjukkan keamanan yang bersifat normal kepada penunjukkan keamanan yang bersifat tanggap.

Level pengamanan 3: menandakan penunjukkan keamanan yang bersifat luar biasa, dengan penerapan tingkat keamanan di tingkat ini menunjukkan ada risiko yang mungkin atau sedang terjadi suatu kejadian/ insiden. Tingkat keamanan yang bersifat luar biasa ini menunjukkan tingkat dimana tindakan perlindungan keamanan harus bersifat lebih spesifik, perlindungan keamanan ini harus dipertahankan untuk jangka waktu yang tidak terbatas ketika insiden

Indonesia, Peraturan Pemerintah Republik Indonesia tentang Pelaksanaan Kitab Undang-Undang Hukum Acara Pidana, PP No. 27 Tahun 1983, pasal 2 ayat 1 (b); Indonesia, Undang-undang tentang Pelayaran, UU No. 17 Tahun 2008, pasal 208 ayat 2.

8 International Ship and Port Facility Security Code, loc. cit. 
keamanan sedang atau segera terjadi, walau penunjukkannya masih belum mengidentifikasi target secara khusus. Pengaturan perlindungan tingkat keamanan yang bersifat luar biasa ini harus ditetapkan hanya selama ancaman keamanan diidentifikasi atau terjadinya insiden keamanan yang sebenarnya.

Ino

PREVENTIONREGULATION

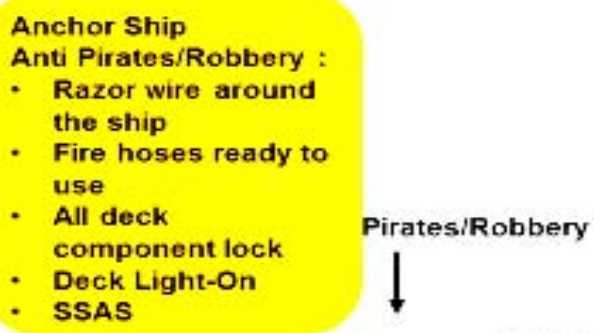

Tabel 2

Alur Sistem Pengamanan Kapal menurut IMO

Penjelasan dari IMO Prevention Regulation pada saat kapal berlabuh pemilik kapal harus tanggap bahaya untuk pencurian ataupun perampokan dengan memberikan kawat berduri di sekeliling kapal, tembakan sinyal api tanda bahaya harus siap digunakan, setiap pintu dek kapal harus selalu terkunci, posisi dek kapal harus selalu diterangi lampu, sistim sinyal pengamanan harus diaktifkan. Apabila akan terjadi pencurian ataupun perampokan maka sistem sinyal pengamanan akan menyala kemudian pemilik kapal harus mengirimkan sinyal tanda bahaya tersebut kepada keamanan pelabuhan selanjutnya diteruskan kepada Syahbandar selaku komite keamanan pelabuhan. 
Pada dasarnya Negara Republik Indonesia adalah anggota Organisasi Dewan International Maritim (IMO) yang telah meratifikasi konvensi SOLAS dimana telah memberlakukan sepenuhnya implementasi ISPS Code yang mempunyai maksud serta tujuan untuk menjadikan standar nasional. Tujuan dari penerapan ISPS Code adalah menyediakan sebuah standar baku, sebuah kerangka kerja yang konsisten untuk mengevaluasi semua risiko, kemudian untuk meminimalisir semua ancaman dengan merubah nilai dari suatu kerentanan terhadap kapalkapal berbendera asing yang akan memasuki wilayah perairan pelabuhan dengan mengutamakan semua fasilitas pelabuhan melalui perencanaan kemudian menentukan tingkat keamanan sesuai standar baku dan langkah-langkah keamanan yang diperlukan sesuai standar yang berlaku.

2. Kewenangan tertinggi dalam menjaga keamanan dan keselamatan pada kapal-kapal yang berlabuh di perairan sekitar Batam sesuai dengan Undang-undang Nomor 17 tahun 2008.

Undang-undang Nomor 17 Tahun 2008 menegaskan bahwa komite keamanan pelabuhan yaitu Syahbandar berperan aktif dalam kegiatan perekonomian nasional dan melaksanakan semua fungsi dilakukannya pengawasan dan penegakan hukum, sarana bantu navigasi, pelabuhan, dan perlindungan lingkungan maritim di pelabuhan ${ }^{9}$.

Menurut peraturan perundang undangan di atas tugas untuk melaksanakan pengawasan oleh Syahbandar tidak hanya terpusat pada kegiatan pelayaran saja, melainkan pada keseluruhan kegiatan didalam pelabuhan antara lain, kegiatan penyelamatan dan melakukan suatu kondisi kerja bawah air, pengerukan dan pemekaran daerah pelabuhan atau reklamasi, penanggulangan pencemaran, perlindungan terhadap lingkungan maritim ${ }^{10}$ di sekitar pelabuhan, serta melaksanakan bantuan pencarian dan penyelamatan terhadap kapal.

Sesuai Undang-undang No. 17 Tahun 2008 pasal 212 ayat 2 bahwa Syahbandar dapat meminta bantuan kepada Polri dan TNI untuk segera mengamankan kapal yang berlabuh saat terjadi suatu tindakan pencurian atau berupa tindakan perompakan dan dipertegas kembali di dalam Undang-undang No. 17 Tahun 2008 pada pasal 212 ayat 3 menjelaskan bahwa bantuan keamanan dan ketertiban dibawah aturan kewenangan Syahbandar. Dimana bantuan keamanan dan ketertiban di pelabuhan tersebut dibawah koordinasi dalam kewenangan Syahbandar dan tergantung permasalahan yang terjadi di atas kapal, karena setiap permasalahan yang timbul akan berbeda penanganannya menurut tugas dan tanggung jawab instansi yang terkait.

9 Indonesia, Undang-undang tentang Pelayaran, UU No. 17 Tahun 2008, pasal 212 ayat 1.

${ }^{10}$ Indonesia, Undang-undang tentang Pelayaran, UU No. 17 Tahun 2008, pasal 208 ayat 1 
Pengertian dari keselamatan itu sendiri sesuai dengan UndangUndang Nomor 17 Tahun 2008 pasal 1 butir 34 berbunyi: “Keadaan kapal yang memenuhi persyaratan material, konstruksi kapal, kegiatan perencanaan bangunan serta stabilitas kapal, melakukan uji layak mesin dan pemasangan kelistrikan kapal, tata susunan perlengkapan kapal termasuk didalamnya berbagai fasilitas perlengkapan alat penolong dan radio transmisi kapal serta prasarana elektronika kapal".

Undang-undang Nomor 17 Tahun 2008 juga menyebutkan tanggung jawab Syahbandar ${ }^{11}$ dalam hal fungsi mewujudkan keselamatan dan terciptanya keamanan pelayaran termasuk didalamnya pada kondisi kapal-kapal berlabuh (drop anchor).

Sesuai dengan diterbitkannya ketentuan yang menyatakan kesepakatan Internasional Syahbandar selaku komite keamanan Pelabuhan (Port Security Committee), dalam kewenangannya dapat meminta bantuan dalam pelaksanaan tugasnya kepada Polri dan TNI. Didalam ketentuan pelaksanaan "peraturan perundang undangan No. 17 Tahun 2008" tentang pelayaran sebagaimana dimaksud Pasal 5 ayat (1) menyebutkan bahwa tata kelola kegiatan pelayaran berunsurkan negara dan pembinaannya dilaksanakan oleh Pemerintah Daerah meliputi segala pengaturan, semua pengendalian dan dilakukannya pengawasan.

Pelayaran sebagai kegiatan pengusahaan bertujuan sebagai tempat sandar kapal, aktifitas domestik untuk keluar masuk penumpang, dan pada saat melakukan kegiatan bongkar muat barang, dapat berupa wilayah yang luas seperti terminal serta tempat berlabuhnya kapal dimana dilengkapi dengan fasilitas keselamatan dan keamanan pelayaran yang mana memberikan tujuan sebagai sarana penunjang angkutan laut di pelabuhan agar menjadi tempat perpindahan transportasi angkutan. Perlu digarisbawahi bahwa adanya salah satu fungsi dari pelabuhan adalah memiliki fasilitas keselamatan dan keamanan bagi kapal-kapal yang berlabuh didalamnya.

Jadi sudah jelas bahwa kewenangan tertinggi ada pada Syahbandar terhadap aturan perundang undangan kepada keselamatan dan keamanan kapal-kapal yang sedang berlabuh berdasar landasan hukum sesuai Undang-undang Nomor 17 Tahun 2008.

\section{Undang-undang Nomor 17 tahun 2008 belum di implementasikan dengan benar khususnya pada sektor keamanan kapal-kapal yang berlabuh di perairan sekitar Batam}

Indonesia sebagai negara yang memiliki wilayah yuridiksi laut yang sangat luas, memiliki banyak permasalahan sehubungan dengan wilayah lautnya. Kendala pada aspek yuridis dapat dijabarkan bahwa didalam perundang undangan yang telah mengatur dengan jelas mengenai

11 Indonesia, Undang-undang tentang Pelayaran, UU No. 17 Tahun 2008, pasal 80 ayat 4. 
penegakan hukum di wilayah hukum perairan Indonesia, dalam satu undang-undang subyek penegak hukum tersebut bisa lebih dari satu instansi/ lembaga. Dalam situasi dan kondisi ketidak harmonisnya hubungan sektoral seperti ini menimbulkan keadaan yang bisa memunculkan perbedaan persepsi fungsi dan kewenangan mengarah kepada ego instansional.

Perbedaan persepsi fungsi dan kewenangan tersebut sangat memungkinkan memicunya koordinasi yang tidak jelas berakibat kepada proses penegakan hukum dan keamanan di laut sehingga pada akhirnya segala keadaan yang timbul terhadap keselamatan dan keamanan di wilayah perairan Indonesia menjadi tidak efisien dan efekif didalam prosesnya.

Definisi perairan menurut Undang-Undang Nomor 17 Tahun 2008 pasal 1 butir 2 berbunyi "Laut territorial Indonesia beserta perairan kepulauan dan perairan pedalamannya". Wilayah perairan Indonesia dipergunakan sebagian wilayahnya sebagai pelabuhan yang memiliki definisi pelabuhan sebagai tempat yang dikelompokkan menjadi daratan dan/ atau wilayah perairan dengan batas-batas tertentu yang telah disepakati bersama oleh semua pihak.

Akan tetapi disisi lainnya didalam Undang-undang yang sama yaitu Undang-undang No. 17 Tahun 2008 pasal 276 ayat 2 menyebutkan bahwa dalam pelaksanaan fungsi terselenggaranya suatu keselamatan dan terciptanya keamanan di laut dilakukan oleh penjaga laut dan pantai. Sementara didalam melaksanakan tugasnya dalam pengamanan kapal yang berlabuh, sarana dan fasilitas yang dimiliki TNI lebih dominan berupa kapal perang yang tersebar di berbagai lokasi strategis sehingga penyalahgunaan wewenang sering terjadi.

Sangat disayangkan bahwa sarana maupun prasarana yang dimiliki Syahbandar sendiri sampai saat ini masih sangat minim akan jumlah armada yang dimilikinya. Jadi sejauh ini ketika ada permasalahan di perairan Batam atau khususnya di pelabuhan, pihak Syahbandar sendiri sering bergantung pada LANAL (TNI AL) untuk meminjam armada kapal TNI AL sebagai alat transportasi maupun mobilisasi ketika melakukan kegiatan operasional mereka.

Teori Penegakan Hukum Soerjono Soekanto masih sangat relevan untuk memberikan solusi dari permasalahan yang timbul. Secara jelas menyebutkan terperinci bahwa faktor-faktor yang mempengaruhi ditegakkannya proses penegakan hukum meliputi: Faktor Hukum; Faktor Penegakan Hukum; Faktor Sarana atau Fasilitas Pendukung; Faktor Masyarakat; dan, Faktor Kebudayaan. Upaya pelaksanaan kepentingan dalam penegakan dari sudut pandang subjeknya maka semua subyek harus melibatkan hukum dalam setiap hubungan hukum, kepada siapa saja berlangsungnya aturan hukum itu dengan normatif didasarkan kepada norma norma aturan hukum yang berlaku, untuk itu disimpulkan bahwa pelaksanaan penegakan aturan hukum sudah terpenuhi. 
Penegakan hukum dalam arti sempit hanya menyangkut soal kegiatan penegakan peraturan informal dan hanya peraturan penegakan secara tertulis. Tujuan hukum adalah terciptanya kedamaian hidup meliputi ketertiban eksternal pribadi secara individu dan mewujudkan ketenangan secara pribadi internal, bahwa hukum itu secara hirarki memberikan pengabdian kepada tujuan negara, yaitu mendatangkan kebahagiaan dan terutama kemakmuran para setiap rakyatnya telah tercantum didalam alinea keempat dari UUD 1945.

Meningkatkan penyelenggaraan kegiatan pelayaran dengan secara optimal sebagaimana "peraturan perundang undangan No. 17 Tahun 2008" tentang pelayaran bahwa pada Pasal 274 ayat (1); dan (4) menerangkan dengan jelas dan terperinci bahwa seluruh warga masyarakat mempunyai dan memiliki kesempatan yang sama luasnya untuk ikut berperan serta dalam kegiatan pelayaran serta turut serta ikut bertanggung jawab dalam menjaga ketertiban serta keselamatan keamanan kegiatan pelayaran.

Namun oleh peneliti ditemukan permasalahan yang terjadi di lapangan yaitu dengan banyaknya pemegang kewenangan di dunia pelayaran maka sering terjadi benturan kepentingan dan kekuasaan antar lembaga/instansi. Benturan ini berdampak sangat serius terhadap para owner kapal yang akan berlabuh (drop anchor) di perairan Batam khususnya.

Undang-undang Nomor 17 Tahun 2008 menegaskan bahwa komite keamanan pelabuhan yaitu Syahbandar berperan aktif dalam kegiatan perekonomian nasional dan melaksanakan semua fungsi dilakukannya pengwasan dan penegakan hukum, sarana bantu navigasi, pelabuhan, dan perlindungan lingkungan maritim di pelabuhan ${ }^{12}$.

Menurut peraturan perundang undangan di atas tugas untuk melaksanakan pengawasan oleh Syahbandar tidak hanya terpusat pada kegiatan pelayaran saja, melainkan pada keseluruhan kegiatan didalam pelabuhan antara lain, kegiatan penyelamatan dan melakukan suatu kondisi kerja bawah air, pengerukan dan pemekaran daerah pelabuhan atau reklamasi, penanggulangan pencemaran, perlindungan terhadap lingkungan maritim ${ }^{13}$ di sekitar pelabuhan, serta melaksanakan bantuan pencarian dan penyelamatan terhadap kapal.

Bahwa kewenangan tertinggi sesuai Undang-undang No. 17 Tahun 2008 menerangkan tentang Syahbandar yang dapat dijabarkan sesuai pasal 211

ayat (1) :

"Syahbandar memiliki kewenangan tertinggi melaksanakan semua kegiatan pengusahaan dan untuk memperlancar semua kegiatannya

12 Indonesia, Undang-undang tentang Pelayaran, UU No. 17 Tahun 2008, pasal 212 ayat 1.

13 Indonesia, Undang-undang tentang Pelayaran, UU No. 17 Tahun 2008, pasal 208 ayat 1 
dapat sepenuhnya melakukan komando untuk meminta bantuan kepada lembaga penegak pemerintah lainnya."

ayat (2) :

"Syahbandar melakukan pelaksanaan koordinasi yang dilaksanakan dengan baik agar pengawasan dan penegakan hukum demi terwujudnya keselamatan dan terciptanya keamanan pelayaran".

Undang-undang No. 17 Tahun 2008 tentang Pelayaran Pasal 212 juga menyebutkan dengan jelas bahwa dalam melaksanakan keamanan dan ketertiban sesuai konvensi internasional:

ayat (1) :

"Syahbandar bertindak dalam pelaksanaan tugasnya selaku komite keamanan pelabuhan"

ayat (2) :

"Syahbandar dapat meminta bantuan dalam pelaksanaan tugasnya kepada Polri dan TNI."

ayat (3) :

"Syahbandar memiliki kewenangan untuk melakukan koordinasi bantuan keamanan dan ketertiban".

Kewenangan didalam Undang-undang No. 17 Tahun 2008 pasal 276 tentang Pelayaran menyebutkan bahwa Syahbandar memiliki kewajiban untuk penyelenggaraan keselamatan dan keamanan di laut, dalam hal ini secara eksplisit di koordinasikan dengan Badan Kesatuan Penjagaan Laut dan Pantai (KPLP) atau biasa disebut sebagai Indonesian Sea and Coastguards. Badan Kesatuan Penjagaan Laut dan Pantai (KPLP) atau biasa disebut sebagai Indonesian Sea and Coastguards berada di bawah wewenang Direktorat Jenderal Perhubungan Laut bertanggung jawab mempunyai kewenangan untuk melaksanakan tugas berpatroli di laut, melaksanakan tugas pengejaran seketika, melaksanakan tugas yakni dengan memberhentikan kapal-kapal kemudian memeriksanya serta melaksanakan tugas melakukan penyidikan.

Dalam menjalankan pelaksanaan tugasnya telah diatur didalam perundang undangan Nomor 17 tahun 2008 pada pasal 207 ayat (1) bahwa Syahbandar melaksanakan tugas sebagai Pejabat Penyidik Pegawai Negeri Sipil (PPNS) yang dalam pelaksanaan tugas dan kewenangan dapat menggunakan semua fasilitas negara seperti fasilitas kapal laut maupun semua fasilitas pesawat udara.

Ada delapan kewenangan yang dimiliki Syahbandar sebagai kepala pelabuhan, yakni :

1. Memberikan koordinasi kepada seluruh kegiatan pemerintahan di pelabuhan;

2. Memeriksa, menyimpan surat resmi dokumen dan warta kapal; 
3. Mengeluarkan persetujuan atas semua kegiatan kapal;

4. Melakukan pemeriksaan kapal secara keseluruhan;

5. Mengeluarkan Surat Persetujuan Berlayar;

6. Melakukan pemeriksaan atas kapal saat timbul kecelakaan;

7. Menahan kapal atas perintah pengadilan;

8. Melaksanakan pemeriksaan daftar awak kapal.

Implementasi Undang-undang No. 17 Tahun 2008 pada Sektor Keamanan Kapal yang Berlabuh terhadap teori Soerjono Soekanto bahwa ditinjau dari isinya kaidah hukum terbagi menjadi tiga bagian. Salah satunya kaidah hukum berisi sebuah perintah, yang mana mau tidak mau harus tetap dijalankan atau ditaati kemudian kaidah hukum bersisi larangan dan kaidah hukum yang berisi suatu asas tata aturan hukum perkenaan.

Peneliti menemukan hasil dari penelitian $M$. Ihsan ${ }^{14}$ bahwa ditetapkannya Undang-Undang Nomor 17 Tahun 2008 tentang Pelayaran, telah mengatur tentang bidang kepelabuhanan yang memuat ketentuan mengenai penghapusan monopoli dalam penyelenggaran kegiatan di pelabuhan, selanjutnya untuk memberikan pemisah antara fungsi sebagai regulator dan fungsi sebagai operator didalam peran pemerintah dan swasta bertujuan untuk melaksanakan porsinya di dalam penyelenggaraan kepelabuhanan.

Berdasarkan uraian yang telah disebutkan maka peneliti berkesimpulan bahwa efektifitas implementasi dari hukum Soerjono Soekanto ${ }^{15}$ ditentukan oleh 5 faktor, yakni :

1. Faktor hukumnya.

2. Faktor penegak hukum.

3. Faktor sarana atau fasilitas yang efektif agar dapat terpenuhinya kegiatan pelaksanaan penegakan hukum.

4. Faktor masyarakat dimana keadaan hukum tersebut berlaku.

5. Faktor Kebudayaan sebagai karya cipta.

Syahbandar memiliki fungsi memberikan keselamatan dan keamanan bagi pelayaran mencakup pelaksanaan, melakukan pengawasan dan menegakkan aturan hukum didalam angkutan perairan, wilayah kepelabuhan, dan melaksanakan perlindungan maritim $^{16}$ di wilayah pelabuhan.

14 Ihsan, M. Pengaruh Tumpang Tindih Aturan Yang Terkait Penegakan Hukum Di Laut Terhadap Dunia Usaha Di Batam (Batam: Universitas International Batam, 2014)

15 Soekanto, Soerjono. Faktor-Faktor Yang Mempengaruhi Penegakan Hukum (Jakarta: PT. Raja Grafindo Persada, 2008), hlm 44.

${ }^{16}$ Darmawan, Laksamana Muda (Purn) TNI, op. cit. hlm. 4. 
Setiap kapal baik sebagai kapal domestik atau kapal berbendera asing yang akan atau sedang memasuki wilayah pelabuhan, pada saat melakukan segala kegiatan di pelabuhan, dan pada saat akan dengan segera keluar dari wilayah pelabuhan, diperintahkan dengan tegas menuruti peraturan tata kelola pelabuhan dan menjalankan arahan perintah Syahbandar yang mana semua kepentingan tersebut sebagai upaya untuk kelancaran lalu lintas kapal, memberikan keamanan kepada kapal yang berlabuh, mengelola dalam pengangkutan penumpang dan/atau barang, memberikan jaminan atas keselamatan dan keamanan pada saat berlayar, serta dapat menjadi tempat perpindahan kedalam ataupun keluar pelabuhan yang diharapkan menciptakan perekonomian nasional terutama perekonomian di daerah.

Peran pemerintah haruslah tegas untuk tercapainya keselamatan dan keamanan pelayaran dengan menerbitkan Undang-undang yang jelas sesuai fungsi dari masing-masing instansi/ badan penegakan hukum yang ada di laut. Dengan peran serta pemerintah maka KPLP dapat fokus dan bertanggung jawab kepada keselamatan dan keamanan pelayaran agar TNI dan POLAIR bertanggung jawab terhadap kedaulatan Negara Republik Indonesia.

Dalam mewujudkan kedaulatan Negara Kesatuan Republik Indonesia sebagai poros maritim dunia diperlukan berbagai program penunjang utama meliputi revitalisasi pada sektor ekonomi kelautan, penguatan didalam keselamatan dan keamanan di wilayah perairan Indonesia, pengembangan konektivitas di bidang maritim, merehabilitasi kerusakan lingkungan dengan meningkatkan pengelolaan kawasan secara terpadu, serta peningkatan kualitas dan kuantitas sumber daya manusia dibidang kelautan.

Sesuai "Undang-undang Nomor 32 Tahun 2014 pasal 3" menyebutkan bahwa penyelenggaraan kelautan dilaksanakan oleh Menteri bertujuan untuk menyelenggarakan urusan pemerintahan di bidang kelautan dan menegaskan bahwa negara Indonesia disebut sebagai negara kepulauan, mendayagunakan dan mengembangkan sumber daya kelautan dengan mewujudkan wilayah laut yang aman dengan memajukan budaya dan pengetahuan tentang kepastian hukum kemudian agar pengembangan hukum laut tersebut bertujuan untuk kepentingan bangsa.

Syahbandar memiliki fungsi memberikan keselamatan dan keamanan bagi pelayaran mencakup pelaksanaan, melakukan pengawasan dan menegakkan aturan hukum didalam angkutan perairan, wilayah kepelabuhan, dan melaksanakan perlindungan maritim di wilayah pelabuhan. Setiap kapal baik sebagai kapal domestik atau kapal berbendera asing yang akan atau sedang memasuki wilayah pelabuhan, pada saat melakukan segala kegiatan di pelabuhan, dan pada saat akan dengan segera keluar dari wilayah 
pelabuhan, diperintahkan dengan tegas menuruti peraturan tata kelola pelabuhan dan menjalankan arahan perintah Syahbandar yang mana semua kepentingan tersebut sebagai upaya untuk kelancaran lalu lintas kapal, memberikan keamanan kepada kapal yang berlabuh, mengelola dalam pengangkutan penumpang dan/atau barang, memberikan jaminan atas keselamatan dan keamanan pada saat berlayar, serta dapat menjadi tempat perpindahan kedalam ataupun keluar pelabuhan yang diharapkan menciptakan perekonomian nasional terutama perekonomian di daerah. Syahbandar mempunyai tugas melakukan kewenangan pengawasan dipenuhinya ketentuan peraturan perundang-undangan, akan tetapi didalam melaksanakan fungsi kewenangannya tersebut lembaga/ instansi lain juga melaksanakan terwujudnya ketentuan peraturan perundang undangan sehingga pentingnya mempunyai mentalitas atau kepribadian petugas penegak hukum yang baik agar tidak menimbulkan terjadinya tumpang tindih kewenangan didalam terciptanya penegakan hukum. 


\section{E. Kesimpulan}

1. Standart Operasi Prosedur (SOP) wajib dimiliki kapal-kapal yang sedang berlabuh di perairan sesuai dengan IMO regulation dan ISPS code untuk menjaga keselamatan dan menjamin keamanan.

Regulasi IMO dan ISPS code mensyaratkan semua kapal-kapal harus menyediakan sistem waspada pengamanan kapal (Ship Security Alert Sistem) yang terhubung dengan sentral stasiun pemancar yang ada di pelabuhan terdekat, agar aparat keamanan segera datang memberi bantuan bila terjadi kondisi yang mengancam. Seluruh regulasi tersebut harus wajib dimiliki oleh setiap pemilik kapal, dikarenakan sebagai landasan hukum ketika terciptanya kondisi pembajakan atas kapal atau situasi emergency. Penerapan ISPS Code bertujuan menyediakan sebuah standar baku, sebuah kerangka kerja konsisten guna mengevaluasi semua risiko, meminimalisir semua ancaman dengan mengutamakan semua fasilitas pelabuhan melalui perencanaan kemudian menentukan tingkat keamanan sesuai standar baku dan langkah-langkah keamanan yang diperlukan sesuai standar yang berlaku.

2. Kewenangan tertinggi dalam menjaga keamanan dan keselamatan pada kapal-kapal yang berlabuh di perairan sekitar Batam sesuai dengan Undang-undang Nomor 17 tahun 2008.

Kewenangan Syahbandar di perairan sekitar Batam masih dapat di intregasikan dengan baik namun tidak menutup kemungkinan wilayah perairan yang luas akan mengundang berbagai ancaman laut, untuk itu perlu dilakukan peningkatan pelayanan keamanan dan keselamatan kapal-kapal yang berlabuh dengan cara memperbaiki sarana dan fasilitas yang dimiliki oleh Syahbandar melalui KPLP yang mana hanya memiliki dukungan 2 unit kapal patroli ukuran 40 meter bertugas melakukan pengawasan di kawasan perairan Batam. Kewenangan tertinggi dalam menjaga keamanan dan keselamatan pada kapal-kapal sesuai dengan peraturan yang berlaku ada pada Syahbandar dan sesuai Undang-undang Nomor 17 Tahun 2008 pasal 212 ayat 2 menyebutkan Syahbandar dapat meminta bantuan kepada Polri dan TNI untuk segera mengamankan kapal yang berlabuh saat terjadi suatu tindakan pencurian atau berupa tindakan perompakan dan dipertegas kembali di dalam Undang-undang No. 17 Tahun 2008 pada pasal 212 ayat 3 menjelaskan bahwa bantuan keamanan dan ketertiban dibawah aturan kewenangan Syahbandar. Sarana serta fasilitas yang melekat pada Syahbandar yakni selaku pemangku kewenangan tertinggi untuk menjaga agar terciptanya keselamatan dan mewujudkan keamanan bagi kapal yang berlayar ataupun berlabuh harus terwujud dengan baik. 
3. Undang-undang Nomor 17 tahun 2008 belum di implementasikan dengan benar khususnya pada sektor keamanan kapal-kapal yang berlabuh di perairan sekitar Batam.

Kedudukan Syahbandar dalam konsepsi hukum laut internasional sebagai commander atau leading sector utama untuk menjaga keselamatan dan keamanan wilayah negara dalam hal ini wilayah lingkungan laut masih sangat jauh untuk dapat di implementasikan dengan baik di wilayah perairan teritorial Indonesia khususnya perairan sekitar Batam, dikarenakan sarana dan fasilitas yang dimiliki Syahbandar melalui KPLP masih kurang bila dibandingkan sarana dan prasarana yang dimiliki instansi/lembaga hukum laut lainnya.

Undang-undang yang sama yaitu Undang-undang No. 17 Tahun 2008 pasal 276 ayat 2 menyebutkan bahwa dalam pelaksanaan fungsi terselenggaranya suatu keselamatan dan terciptanya keamanan di laut dilakukan oleh penjaga laut dan pantai. Sementara didalam melaksanakan tugasnya dalam pengamanan kapal yang berlabuh, sarana dan fasilitas yang dimiliki TNI lebih dominan berupa kapal perang yang tersebar di berbagai lokasi strategis sehingga penyalahgunaan wewenang sering terjadi.

Syahbandar selaku pemangku kewenangan tertinggi dalam menjaga keselamatan dan menciptakan keamanan di perairan sesuai Undangundang Nomor 17 Tahun 2008 berperan penting dalam sistem kepelabuhanan baik dalam kegiatan pelayaran, kewenangan penegakan hukum, maupun berkoordinasi dengan seluruh instansi/ lembaga atas berlangsungnya kegiatan pelabuhan. Dimana bantuan keamanan dan ketertiban di pelabuhan tersebut dibawah koordinasi dalam kewenangan Syahbandar tergantung permasalahan yang terjadi di atas kapal, karena setiap permasalahan yang timbul akan berbeda penanganannya menurut tugas dan tanggung jawab instansi yang terkait. Sangat disayangkan bahwa sarana maupun prasarana yang dimiliki Syahbandar sendiri sampai saat ini masih sangat minim akan jumlah armada yang dimilikinya. Jadi sejauh ini ketika ada permasalahan di perairan Batam atau khususnya di pelabuhan, pihak Syahbandar sendiri sering bergantung pada LANAL TNI AL untuk meminjam armada kapal TNI AL sebagai alat transportasi maupun mobilisasi ketika melakukan kegiatan operasional mereka. 


\section{DAFTAR PUSTAKA}

\section{Buku}

Albitani, Muchid, 2016, Berburu Rente di Pulau Batam, Deepublish, Yogyakarta.

Darmawan, 2018, Menyibak Gelombang Menuju Negara Maritim, Yayasan Pustaka Obor Indonesia, Jakarta.

Hussein Umar, 2001, Hukum Maritim dan Masalah-masalah Pelayaran di Indonesia, Pustaka Sinar Harapan, Jakarta.

Ihsan, M, 2014, Pengaruh Tumpang Tindih Aturan Yang Terkait Penegakan Hukum Di Laut Terhadap Dunia Usaha Di Batam, Universitas International Batam, Batam.

Olga Soejono, 1987, "Penerapan Peraturan Perundang-undangan di Bidang Pelabuhan dalam Kaitannya dengan Organisasi dan Tata Kerja Administrator Pelabuhan," dalam Peningkatan Peranan Hukum dan Perlindungan Hukum dalam Kegiatan Perhubungan Laut, Ind.Hill-Co, Jakarta.

Soekanto, Soerjono, 2008, Faktor-Faktor Yang Mempengaruhi Penegakan Hukum, PT. Raja Grafindo Persada, Jakarta.

\section{Artikel}

SOLAS. International Convention for The Safety of Life at Sea: Lloyd's Register Rule Finder 2005-Version 9.4

\section{Internet}

International Ship and Port Facility Security Code

https://ispscode.wordpress.com/2013/02/07/apa-yang-dimaksud-denganisps-code/ diakses pada tanggal 30 Desember 2018.

\section{Peraturan Perundang-Undangan}

Undang-undang tentang Pelayaran, Undang-undang No. 17 Tahun 2008, tentang Pelayaran (Lembaran Negara Republik Indonesia Tahun 2008 Nomor 64)

Peraturan Pemerintah Republik Indonesia tentang Kawasan Perdagangan Bebas dan Pelabuhan Bebas Batam, PP No. 46 Tahun 2007

Peraturan Pemerintah Republik Indonesia tentang Pelaksanaan Kitab Undang-Undang Hukum Acara Pidana, PP No. 27 Tahun 1983, pasal 2 ayat 1 (b) 